\title{
Transmission Mechanism of Intergenerational Mobility in Socio-Economic Status
}

\author{
Malik Muhammad and Shabib Haider Syed ${ }^{1}$
}

\begin{abstract}
The strength of intergenerational mobility in socio-economic status represents the equality of opportunities available to the citizens. It affects motivation, efforts, innovations and productivity of individuals and thereby overall inequality and economic growth of a country. In less mobile societies, opportunities of success are not equal and are limited for the less educated poor segment. Not only their current but also the future generation remains under developed. Skills and talents of the poor are wasted and their motivations of getting education and working hard decrease. This impedes them to move to the high status occupations. There are different mechanisms through which the socio-economic status is transmitted from the generation of the parents to their children. At family level, the investment on the part of the parents in the form of social, human and health capital of their children determine their socio-economic status. At social level, environment available to an individual, social network, self-identity in the society etc. play their roles in intergenerational mobility of socio-economic status. Similarly, genes affect the level of ability of the children and transfer cognitive and non-cognitive skills from the parents to the children. Genes also affect human capital through health of the children which in turn determines their level of income. Finally, the pattern of marriages plays its role in the mobility of socio-economic status as parents give due consideration on the socio economic status of the children's partners. The trend to marry in the similar families causes persistence in socio-economic status.
\end{abstract}

Keywords: Socio-economic status, Intergenerational Mobility, Measurement and Transmission Mechanism

JEL Classification: J60, J62

1. Introduction

Almost all the countries around the world face problems of increase in inequalities and their persistence. They experience inequality in opportunities (education and

\footnotetext{
${ }^{1}$ The authors are Assistant Professor and Professor at International Institute of Islamic Economics, International Islamic University Islamabad and Department of Economics, Forman Christian College (A Chartered University), Lahore, respectively.

Corresponding author's Email: malikmuhammad@iiu.edu.pk
} 
occupation) as well as inequality in outcomes (income, wealth, and consumption). Numerous research work has been carried out to estimate inequalities and to find out factors responsible for them. Inequality in opportunities is more important issue to be addressed because a problem of inequality in outcomes cannot be solved unless we identify inequality in opportunities ${ }^{2}$. By equality of opportunities we mean that children belonging to poor (with low socio-economic status) families should have the same opportunities for success (to achieve high socio-economic status) as those belonging to rich families (with high socio-economic status).

Some specific social classes are excluded from the process of capabilities formation and opportunities of income generation. As a result, both current and future generations experience backwardness, deprivation and increases in poverty. There is exclusion of the poor class from participation in the activities pertaining to income generation because of their weak financial position within the society, on one hand. On the other hand, the low socioeconomic status of the poor results in their exclusion from the opportunities of capability formation. This causes a decline in the quality of their human capital and hence causes a reduction in the income of their coming generation as well. The extent to which the human capital impacts economic growth is noteworthy; this in turn affects fertility and mortality (Meltzer, 1992). Decision about fertility and education of children depends on the preferences and constraints faced by the parents. This provides a strong basis for the family's role in the human capital transmission in the intergenerational mobility theories ${ }^{3}$.

Mobility is desirable as it assists in the individual's placement in the society in accordance to his or her competence as compared to their social origin (Hout, 1988). Persistence in socio-economic status would mean that a person born in the poor class will be unable to improve his socioeconomic standings and therefore the inequality will transcend in the next generation. Human skills and talents are more likely to be wasted or misallocated in societies where mobility is very low. Talented individuals from the poor families will remain under-developed and their potential will not be fully utilized. Their motivation will direly be affected due to the lack of opportunities. The lesser motivated the individual is the lower in productivity be and hence growth potential of the economy is adversely affected. In this perspective, government should not only finance and provide education to everyone but also ensure the policy of merit in order to equalize the opportunities. However,

\footnotetext{
${ }^{2}$ In an opinion poll, which was conducted in US in March 2009, majority (71 percent) of the respondents consider the equality in opportunity as more important than the equality of outcomes (Breen, 2010).

${ }^{3}$ See for example Becker and Tomes $(1976,1979)$ for detail discussion of altruism and role of families in the educational investment of children
} 
if opportunities for the children are based in and transmitted from the home, then reliance upon the education system or job market to promote integrative goals may be an overly optimistic strategy. In this case, institutional reforms and behavioral changes would be required to improve the socio-economic status of the current generation.

The transfer of the economic and social status from the parental side to their sons is widely studied in the field of social sciences. The first study on intergenerational mobility can be dated back to Galton (1886), a biologist, who regressed height of children on height of parents. Sorokin (1927), a sociologist, formulated 23 mobility tables using data collected between 1900 and 1925 . Occupational mobility has been studied in detail by Ginsberg (1929), Glass (1954) and Goldthrope (1980), amongst other, for Britain and Featherman and Hauser (1978) for the United States of America. The topic of mobility of income was one of the most studied topics among the economists in the later decades of the twentieth century. The pioneer works include Soltow (1965), Wolfe and Sliipe (1965) and Becker and Tomes $(1979,1986)$. Since then, an enormous research has been carried out on income, educational and occupational mobility across the generation.

\section{Meaning of Intergenerational Mobility in Socio-Economic Status}

Socio-economic status is the social standing of an individual or the class to which he/she belongs. It is the integrated economic and sociological measure of work experience that defines socio-economic position of an individual in relation to others. It can be judged through different measures of labor market characteristics that include occupational nature, educational level and income. A socio-economic change that occurs over multiple generations is termed as intergenerational mobility. It is the movement of an individual in relation to socioeconomic position of his/her parents (Mann, 1983). Children of well-educated and rich parents have better chances to move up the ladder of social status as compared to their counterparts belonging to less educated and poor parents. Similarly, the caste status, which is inherited by birth, imposes social restrictions on the traditional assignment of jobs which is one of the biggest obstacles to social mobility of the poor. The son of a poor, uneducated fisherman is likely to be poor, uneducated fisherman because it is very difficult for him to find employment in other occupations. Hence, the interest of such a person to get education is also limited because a large part of the attraction of acquiring education is mainly in its value in getting jobs. 
The social scientists measure mobility as the socioeconomic status of the children as compared to that of their parents. If there is a strong association between the socioeconomic status of the parents and their children, then there is immobility or persistence in the socio-economic status. In this case, the intergenerational transfer of the socio-economic status remains the same. However, the society can be considered more mobile if the linkage between the social and economic status of the parent and the children is weak. In this case the status of a child is different from that of his/her parent. Mobility may be in either direction; upward mobility or downward mobility. An upward mobility is a situation in which the social and economic status of the child is higher than that of the parent. On the other hand, in downward mobility the socio-economic status of a child as adult is lower than that of his/her parent.

Differences in mobility among the societies lead to different consequences. For example, in highly mobile societies, talents of their members are optimally used and thereby are able to grow faster (Weil, 2009). In these types of societies, social conflict can be reduced, and more pressures could be put for redistributive policies. According to Bourguignon et al. (2007), the incentive of working hard increases in a society where rich and poor groups have equal chances of success and failure on the basis of merit. On the other hand, a society where social positions of sons are tied to their fathers through stiff and rigid system creates hurdle in innovations at individual as well as at collective level and restricts equal opportunities (Bourdieu et al., 2009). In such societies, poor are not only under developed, but their talents and skills are also under-utilized or mostly wasted. On the contrary, the families belonging to rich classes spend more on their children's human capital and hence they are able to land occupations of the high status and increase their income levels (Solon et al., 2004). In this situation observing perfect mobility would mean "no return" to human capital. Similarly, genetic differences in ability also cause intergenerational persistence in socio-economic status. So, increasing mobility through assisting the less qualified in terms of employment and payment by compelling the employers would be more costly to society by creating inefficiency and reducing incentive for human capital formation. On the contrary, there will be a rise in the economic inefficiency if children of rich families use connections to get high status jobs even in the presence of better qualified poor children. The intergenerational persistence due to this nepotism is harmful to society. This type of discrimination would lock the people into long-term poverty gaps and inequalities between poor and rich would not only affect the current generation but also the future generation. 


\section{Measuring Socio-Economic Status}

The economists have been using income of an individual as a proxy for the social and economic status. However, there are a lot of drawbacks of using income as a proxy for the aforementioned indicator. It is influenced by time and cycles. It is also affected by individual as well as by aggregated temporary shocks. Moreover, income significantly changes with respect to the lifecycle of the individual and also inter-generationally. So it becomes quite difficult to find a causal linkage between the parent and the children's income.

While studying mobility, we have to depend on survey data collected at household level where current income is reported. The individual's consumption and welfare is determined by the permanent income (Friedman, 1957). Therefore, for measuring income mobility the association should be established between permanent incomes of the two generations. Unfortunately, in most of the available data information about the permanent income is not available. The measurement error in income in the form of transitory fluctuations ${ }^{4}$ causes downward bias and inconsistent estimates (Altonji \& Dunn, 1991). For permanent income, researchers like Solon (1992), Mazumder (2005), Dahl and DeLeire (2008) etc. use mean earnings as a proxy. However, fluctuation in transitory income exhibits U-shaped pattern in the different stages of life - decreases in the early stage of life of an individual reaches minimum level and then increases (Baker \& Solon, 2003). Therefore, using averages as proxy for permanent income, lead to further biasedness. Baker and Solon (2003) argue that fluctuations are minimum at the age of 40 years of an individual; therefore, measuring earnings at that age will minimize the bias. Moreover, the linkage among the earnings of the lifetime and current income fluctuates over the lifecycle of individuals which leads to lifecycle bias in the measurement of earnings profiles. The growth of earnings is flatter for those individuals whose lifetime earnings are low as compared to those who have high lifetime earnings. The earnings gap that is observed in the early ages of high and low earners leads to underestimate the gap in life time earnings. Therefore, age of children and parents are important for getting unbiased estimates of earning elasticity (Jenkins, 1987; Solon, 1992). The problem of life time bias can be handled by using children's and parental income at the same age (Blanden, 2005).

Restricting socio-economic status and its mobility to monetary measures underestimates the role of the socioeconomic background of the individual's family on inequality (Goldberger, 1989). Level of education and occupational status are better correlated with the long-term socio-economic status of an individual. They

${ }^{4}$ Especially in the earning of parent which is used as an explanatory variable 
are highly correlated with earnings and are relatively stable over time (Nickell 1982; Ermisch \& Francesconi, 2002).

Level of education provides information about the lives of individuals they live in. It is less likely to expose to measurement errors. Moreover, plenty of researchers ${ }^{5}$ show that there is a strong linkage between the attainment of higher education and high-income levels and longer life span. Education increases the chances of upward mobility in occupational status as well as the possibility of upward mobility in income (Burns, 2001). It creates mobility aspirations, socializes an individual for better position and prepares for better work role. Moreover, information regarding level of education of father can be easily provided by the sons without any complications, like earnings, in the measurement. Therefore, education is a reasonable proxy to measure overall socio-economic status of individuals and mobility of education, therefore, would mean mobility in overall socio-economic status.

Occupation is another proxy of socio-economic status. It reflects the lives the people live in. According to Giddens (2009),

"Occupation is the most critical factor in an individual's social standing, life chances and level of material comfort...individuals in the same occupation tend to experience similar degrees of social advantage or disadvantage, maintain comparable lifestyles, and share similar opportunities in life”. (p. 443).

Occupation is the intervening activity which links education and earnings (Ducan 1961) and reflects the indirect effect of education on income. Information on occupation can be easily collected and is relatively more reliable as compared to income. It can be easily recalled and cannot be refused easily. Further, information about parental occupational status can be easily reported by their adult children. Occupational status of an individual remains stable for a long period of time (Goldberger, 1989). Improvement in occupational status is a sign of improvement in educational attainment and increase in income of the people. It provides opportunity for individuals to raise living standards of their families. But the pattern and strength of improvement in occupational status depends upon policies affecting the educational sector and the occupation seeking. Better education equips an individual with a high human capital which leads to a good and prestigious occupation and a high level of permanent income.

\footnotetext{
${ }^{5}$ Solon et al., 1994; Blanden, 2009; Black \& Devereux, 2011; Currie \& Almond, 2011 etc.
} 


\section{Mechanisms of Intergenerational Mobility}

There are numbers of ways through which the social and economic status is transferred from parent to their children. These channels are discussed below:

\subsection{Family Transmission Models}

The role of family has long been recognized in the determination of intergenerational mobility in terms of inequality as well as socio economic status. It acts as a key social institution that raises inequality in income through their behavior which produces links between the parental and children wealth (Knight, 1935). Each family maximizes utility in which parents are altruistic as they are concerned not only about their own utility but also about the utility and socio economic prosperity of their children (Becker \& Tomes, 1979). The parents have the power to influence their children's income through investing not only in their human capital but in their non-human capital as well. This provides the basis to explain intergenerational mobility through families.

Parents neither demand nor legally force their children to pay back the educational expenditure incurred on them. Higher the level of parental income higher will be the level of investment on education of children. Therefore, the level of income of the parents is the key determinant in the educational and human capital levels of their children. Level of education along with ability and labor market luck, determine the income of children. Apart from parental income, parental education influences the level of education of their children through different mechanisms. First, generally income of the highly educated parent is also high which may positively affect the level of education of their children by relaxing financial constraint of the family. Second, educated parents may be more productive and efficient in activities related to children enhancement in terms of human capital. Third, educated parents have greater concern for the education of children as compared to uneducated parents ${ }^{6}$. They can better guide their children in complications of the school system (Becker et al., 2015). Fifth, level of education of a child is influenced by the role model effects as children emulate the parental education (Emran and Shilpi, 2011).

Other than human capital, the income of the family is also associated with the "health capital". Maternal health influences health of a child which in turn determines his human capital formation (Currie \& Almond, 2011) called "The Fetal Origins" hypothesis in the literature. The family background also plays pivotal role

\footnotetext{
${ }^{6}$ Guryan et al. (2008) in American Time Survey show that average time spent with children by educated parents is larger than the uneducated parents.
} 
in the development of the cognitive as well as non-cognitive skills (personality traits) ${ }^{7}$ of a child. Heckman (2008) is the pioneer research study which focuses on the traits of the family in determining socio-economic success. Bowels et al. (2005), in their study for US, find that increase in cognitive test scores increases earnings directly as well as indirectly through increase in level of education. Although, parental income helps in human capital formation which determines the socioeconomic status of a child, however, parenting and mentoring comparatively play more important role in the human capital formation of the children. Spending more time with children and helping them in solving their home assignments are keys to educational success of children.

Further, as a role model, parents influence the preferences of their children. For example, successfulness of parents in some occupation would lead the children to revise their estimation upward about their ability to be successful in similar occupation. Further, risk averse children will prefer to choose familiar parental occupation relative to other alternatives where uncertainty is reduced by revelation of information about parental occupation (Sjogren, 2000). The literature pertaining to the cultural evaluation reveals that there is inspiration among the children regarding the success of the parents (Boyd and Richardson 1985, Henrich and McElreath, 2003). The children follow the tracks of their parents in choosing occupations. For a son (daughter), father (mother) acts as a natural role model. Moreover, father's social network might be more easily accessible to a son and that of mother's can be easily accessed by the daughters. This gender effects contribute in occupational choices. Further, preferences of a child are transmitted through genes, so they have gender dimension. The preferences of a son (daughter) are more likely to be same as his (her) father (mother) as compared to that of his (her) mother (father).

\subsection{Social-Level Transmission Models}

Collective activities or environments have strong influences on children. Among these, some factors such as risk seeking attitude, social norms and

\footnotetext{
${ }^{7}$ These include, known as "The Big Five" in the literature of psychology, (1) openness, (2) conscientiousness, (3) extraversion, (4) agreeableness, and (5) neuroticism. Openness is the degree of intellectual curiosity and shows a preference for novelty. It also shows the degree to which a person is imaginative or independent. Conscientiousness represents the tendency of an individual to be organized, self-discipline, act dutifully, aim for achievement, and prefer planned. Extraversion reflects energy, positive emotions, sociability and the tendency to seek stimulation in the company of others and talkativeness. Agreeableness is the tendency of a person to be sympathetic and cooperative rather than suspicious and aggressive. Neuroticism is the degree of emotional stability and impulse control.
} 
networks, and work ethics are loosely linked with the public policy and are very difficult to change directly through the government policies. However, there are some factors which can be affected, to a large extent, by the public policies. For instance, government policies related to public support for early childhood and education at all levels can help in access to education and human capital formation. Similarly, redistributive policies of the government in the form of taxation and subsidies may cause a reduction or increase in financial constraints and other obstacles in accessing higher education. To understand, for example, provision to the children aged between 5 and 17 without direct charge of education is the responsibility of state in US. So, the level of education considered as a public good is primarily determined by the political mechanism and is dependent upon the preferences and level of income of adults in various districts. Parental income is the key determinant for the type of school the children will be attending but by the law of state the child must be in school during the above-mentioned range of age.

Similarly, researchers who link the socio-economic status of a child to his IQ level, show that IQ of a child is not limited to genetics but also depends upon the environment provided to a child. Duyme et al. (1999) show that children adopted by families with high socio-economic status gained more cognitive skill as compared to those adopted by families with lower socio-economic status.

There are numbers of reasons which explain how neighborhood plays a pivotal role in the mechanism of intergenerational transmission. First reason formalized by Streufert (2000) is the role model. Decisions regarding educational attainments depend upon the perceptions of future economic benefits attached to different levels of education. Assessing the values of these benefits depend on the distributions of level of education and income of a community. Division of communities on the basis of income would mean that different locations produce different inferences about the value of education. Second reason is the influence of individual's self-identity on his choice (Akerlof \& Kranton, 2000). The choices made regarding the level of education and nature of occupation depends on how an individual relates his individuality with others in the community. For example, authors like Ogbu (2003) and Fryer and Torelli, (2010) argue that racial inequality in level of education between black and white is the perception of black that getting high level of education is a form of "acting and serving the white". Due to this perception of the black, they have less attraction and desire to get high level of education. Third reason is the provision of access to information of employment opportunities. Interpersonal hiring networks play an important role for job market outcomes (Bayer et al., 2008). An individual may be termed as disadvantaged if 
information is not available to him/her (Calvo-Armengol \& Jackson, 2004, 2007). In disadvantaged community access to information on job openings is low.

\subsection{Genetic Transmission}

The importance of genes and environment interactions is fully recognized by the behavioral genetics' researchers. Based on review of the literature, Jenson (1969) reports that $80 \%$ of the variation in IQ scores is genetic. Clark (2014) suggests that gene also plays its role in intergenerational mobility. Genes affect intelligence of individuals which is then linked to income. Children's cognitive abilities strongly correlate with that of the parents. Daniels et al. (1997) find that 48 percent of the variation in IQ is genetic. According to Bowles and Gintis (2001), contribution of each of the genetics and environment to their correlation with the intergenerational earnings is 0.2 percent. Jencks and Tach (2006) in their study for Sweden and US find that two-fifths of the intergenerational earnings correlation is explained by genetic similarities. They explain the association among the social economic status of the parent and the children via genetics as;

"If genetic variation affects any of the traits that labor markets reward, then genetic variation will affect economic success. If the labor market still rewards the same traits a generation later and genes still affect these traits, then biological children of a successful parent will still tend to have traits that the labor market rewards, even if the children have no social contact with this parent." (pp. 33)

As health plays a key role in the individual's status attainment, therefore the health transmission through genetics affect the mobility of socioeconomic status. According to McCandless et al. (2004) seventy percent of patients admitted in the pediatric ward in Ohio children's hospital have significant genotype origin. Moreover, presence of genetic mutation is also one of the important factors which causes spread of the genetic diseases. Diseases like Hemophilia and Huntington are highly penetrant. Mutations in genes, i.e. BRCA one and two, are linked with high risks of breast cancers (Ries et al., 2006, Petrucelli et al., 2007)). Though genetic mutations of the diseases like asthma, cardiovascular disease, and diabetes are yet to be discovered but relatives of the individuals suffering from these conditions are more likely to have those same conditions. Heritability estimates for bipolar disorder, autism and schizophrenia are, 80 percent, 90 percent and 75 percent respectively. When it comes to hyperactivity, the heritability ranges from 54 percent to 98 percent (Rutter et al, 1999). So, all these genetic diseases affect the health capital of children through their transformation from their parents and hence impact the economic and social status of their off springs. 


\subsection{Assortative Mating}

Assortative mating is concerned with the marriage patterns in a society. Assortative mating with respect to educational levels, income and family wealth causes intergenerational persistence. There is a decrease in the intergenerational mobility when it comes to higher degree of assertive mating and will increase persistence in the socio-economic status (Holmlund, 2008). While maximizing their utilities, parents not only care about the income of their children, but they also care about the income of the partners of their children (Holmlund, 2008). Therefore, a strong impact of schooling of father in law is found on wages of individuals (Lame \& Schoeni, 1993, 1994). A father in law at high socio-economic status helps to employ his son in law at high socio-economic position. Ermisch et al. (2006) find a significant effect of assertive mating on the persistence of intergenerational socioeconomic status and show that 40 to 50 percent of the mobility estimates can be accounted for by assortative mating ${ }^{8}$.

Educational institutions also play their role in shaping peer groups of individuals where people meet and form couples (Mare, 1991). Especially those institutions which sorts students on the basis of their ability or/and on the basis of family background give a rise to similar and homogenous types of students. Students of these institutions meet and mate with same type of individuals (Holmlund, 2008) and thus lead to persistence in intergenerational socio-economic status.

\section{Conclusion}

Socio-economic status connotes the social and economic well-being of an individual. Income, education and occupations are primary measures of the socioeconomic prosperity. While income is only a monetary measure, occupation represents monetary position, authority and supremacy, power and command over decision making, physical and mental efforts of an individual. However, high status occupation and high level of income, though not impossible, but are challenging without high level of education. In most of the cases, level of education determines the nature of occupation and thereby the level of income.

Intergenerational mobility's strength with respect to socio economic status is a representation of the equality of opportunities that are available for the citizens. It affects motivation, efforts, innovations and productivity of individuals and

\footnotetext{
${ }^{8}$ Also see Blanden (2005) and Hirvonen (2008)
} 
thereby overall inequality and economic growth of a country. It enhances equality of opportunities and reduces inequality. Immobility or less mobility causes under development, deprivation, misallocation of the skills and talent, decrease in attraction and desire to get high education and hinders to move to the high-status occupations. All these factors contribute to more poverty, inequality and slow economic growth.

Four different mechanisms play their role in the attainment and transmission of status. First is the family transmission mechanism in the form of investment of the parents in the human as well as social capital of their off-springs which is a major determinant of their status in the society. Second is the social level transmission mechanism in which work ethics, social network, perception about future benefits and self-identity, environment provided to an individual and political mechanism of the society play their roles in the status attainments. Third is the genetic transmission mechanism. Genes affect intelligence and level of ability of the children and hence play a vital role in transferring cognitive skills as well as non-cognitive skills from the parents to their off springs. Moreover, genes also play their part in the health of children which shapes human capital and in turn determines income level of the children. Fourth transmission mechanism is the assortative mating, in which the marriage pattern affects the intergenerational mobility when it comes to social and economic progress. Parents give due consideration to the status of the children's partners. Therefore, the trend to marry in the similar class and family is one of the main causes of persistence in socioeconomic status.

Education focused redistributive policies of the government in the form of taxation and transfer schemes may reduce financial and other hurdles to accessing higher education and thereby improve socio-economic status of the citizens. Government should insure that a child should be in educational institution within prescribed age. For example, in US there is a policy that individuals with age between 5 to 17 years must be in educational institute. The parent's income levels are a vital determinant in the type of school the child will attend. Once children are in school then financial constraints of parents have less impact on children's education (Bauer and Riphahn, 2009).

Level of education of an individual plays the most important role in determination of high-status occupations. So, improving the educational status will help in improving skills and human capital of individuals and will increase their socio-economic status. Moreover, opportunities of high-status occupations are limited in some regions especially in rural regions; therefore, people are engaged 
in the lower status occupations. Creating the opportunities of high-status occupations in these regions will improve socio-economic status of the individuals living there.

Though it is true that parental income helps in human capital formation which determines the socio-economic status of a child and any parental credit constraint causes a hinder investment in human capital of children, however, parenting and mentoring comparatively play more important role in the human capital formation of children. Spending more time with children and helping in solving their home assignments are keys to educational success of a child and thereby help the children in achieving high status occupations.

Finally, the role of family background cannot be ruled out in the status attainment of a child. Families belonging to the richer classes have high investments in the education of their off springs which enable them to get high status occupations. Therefore, observing perfect mobility would mean "no return" to human capital. Similarly, differences in ability due to genetic also cause persistence in educational and occupational status. Both of these factors cause intergenerational persistence in socio-economic status. Increasing intergenerational mobility by favoring less qualified individuals would be more costly because it will create inefficiency and will reduce incentive to accumulate human capital. However, inefficiency will also arise if children of rich families use connections to get high status jobs in the presence of better qualified poor children. Therefore, merit-based policy will ensure equality of opportunities for every talented one and will eliminate nepotism from the job market. 


\section{References}

Akerlof, G. A., \& Kranton, R. E. (2000). Economics and identity. The Quarterly Journal of Economics, 115(3), 715-753.

Altonji, J., \& Dunn, T. A. (1991). Relationships Among the Family Incomes and Labor Market Outcomes of Relatives. Research in Labor Economics 12: 269-310.

Baker, M., \& Solon, G. (2003). Earnings dynamics and inequality among Canadian men, 1976-1992: evidence from longitudinal income tax records. Journal of Labor Economics, 21(2), 289-321.

Bauer, P.\& Riphahn, T.R. (2009). Kindergarten Enrollment and the Intergenerational Transmission of Education [Electronic resource]/Philipp C. Bauer, Regina T. Riphahn. Institute for the Study of Labor, Discussion Paper (4466).

Bayer, P., Ross, S. L., \& Topa, G. (2008). Place of work and place of residence: Informal hiring networks and labor market outcomes. Journal of Political Economy, 116(6), 1150-1196.

Becker, G. S., \& Tomes, N. (1976). Child endowments and the quantity and quality of children. Journal of Political Economy, 84(4, Part 2), S143-S162.

Becker, G. S., \& Tomes, N. (1979). An equilibrium theory of the distribution of income and intergenerational mobility. Journal of Political Economy, 87(6), 1153-1189.

Becker, G. S., \& Tomes, N. (1986). Human capital and the rise and fall of families. Journal of Labor Economics, 4(3, Part 2), S1-S39.

Becker, G. S., Kominers, S. D., Murphy, K. M., \& Spenkuch, J. L. (2018). A theory of intergenerational mobility. Journal of Political Economy, 126(S1), S7S25.

Black, S. E., \& Devereux, P. J. (2011). Recent Developments in Intergenerational Mobility. Handbook of Labor Economics, 4(B), Ch-16, 1487- 1541.

Blanden, J. (2005). International evidence on intergenerational mobility. Centre for Economic Performance, LSE, London.

Blanden, J. (2009). How much can we learn from international comparisons of intergenerational mobility? London School of Economics and Political Science, LSE Library. 
Blau, P. M., \& Duncan, O. D. (1967). The American occupational structure. New York: John Wiley and Sons.

Bourdieu, J. r. m., Ferrie, J. P., \& Kesztenbaum, L. (2009). Vive la difference? Intergenerational mobility in France and the United States during the nineteenth and twentieth centuries. Journal of Interdisciplinary History, 39(4), 523-557.

Bourguignon, F. o., Ferreira, F. H. G., \& Menendez, M. (2007). Inequality of opportunity in Brazil. Review of income and Wealth, 53(4), 585-618.

Bowles, S., \& Gintis, H. (2001). The inheritance of economic status: Education, class and genetics. International encyclopedia of the social and behavioral sciences: Genetics, behavior and society, 6, 4132-4141.

Bowles, S., t Gintis, H. and Groves, O. M. (2005). Introduction." in Samuel Bowles, Herbert Gintis, and Melissa Osborne Groves, eds., Unequal Chances: Family Background and Economic Success. Princeton, New Jersey: Princeton University Press. pp. 1-22

Boyd, Robert, and Peter J. Richerson (1985). Culture and the Evolutionary Process. Chicago: University of Chicago Press.

Breen, R. (2010). Social Mobility and Equality of Opportunity. The Economic and Social Review, 41(4), 413-428.

Burns, J. (2001). Inheriting the future: the role of family background and neighborhood characteristics in child schooling outcomes in South Africa. Department of Economics, University of Cape Town, Cape Town.

Calvo-Armengol, A., \& Jackson, M. O. (2004). The effects of social networks on employment and inequality. The American Economic Review, 94(3), 426454.

Calvo-Armengol, A., \& Jackson, M. O. (2007). Networks in labor markets: Wage and employment dynamics and inequality. Journal of economic theory, 132(1), 27-46.

Chadwick, L., \& Solon, G. (2002). Intergenerational income mobility among daughters. The American Economic Review, 92(1), 335-344.

Clark, G. (2014). The son also rises: surnames and the history of social mobility: Princeton University Press. 
Currie, J., \& Almond, D. (2011). Human capital development before age five. Handbook of labor economics, 4, 1315-1486.

Dahl, M. W., \& DeLeire, T. (2008). The association between children's earnings and fathers' lifetime earnings: estimates using administrative data. University of Wisconsin-Madison, Institute for Research on Poverty.

Daniels, M., Devlin, B. \& Roeder, K. in Intelligence, Genes and Success: Scientists respond to The Bell Curve (eds Devlin, B., Fienberg, S., Resnick, D. \& Roeder, K.) (Springer, New York, (1997)).

Duncan, O. D. (1961). A socioeconomic index for all occupations. Class: Critical Concepts, 1.

Duyme, M., Dumaret, A.-C., \& Tomkiewicz, S. (1999). How can we boost IQs of Dull Children?: A late adoption study. Proceedings of the National Academy of Sciences, 96(15), 8790-8794.

Emran, M. S., \& Shilpi, F. (2011). Intergenerational Occupational Mobility in Rural Economy Evidence from Nepal and Vietnam. Journal of Human Resources, 46(2), 427-458.

Ermisch, J., Francesconi, M., \& Siedler, T. (2006). Intergenerational mobility and marital sorting. The Economic Journal, 116(513), 659-679.

Featherman, D. L., \& Hauser, R. M. (1978). Opportunity and change. New York: Academic Press.

Friedman, M. (1957). A Theory of the Consumption Function. Princeton University Press, Princeton

Fryer, R. G., \& Torelli, P. (2010). An Empirical Analysis of 'Acting White. Journal of Public Economics, 94(5), 380-396.

Galton, F. (1886). Regression towards mediocrity in hereditary stature. The Journal of the Anthropological Institute of Great Britain and Ireland, 15, 246-263.

Giddens, A. (2009). Sociology (revised and updated with Philip W. Sutton). Polity, Cambridge.

Ginsberg, M. (1929). Interchange between social classes. The Economic Journal, 39(156), 554-565.

Glass, D. V. (ed) (1954). Social Mobility in Britain. London: Routledge 
Goldberger, A. S. (1989). Economic and mechanical models of intergenerational transmission. The American Economic Review, 79(3), 504-513.

Guryan, J., Hurst, E., \& Kearney, M. (2008). Parental education and parental time with children. The Journal of Economic Perspectives, 22(3), 23-46

Heckman, J. J. (2008). Schools, skills, and synapses. Economic inquiry, 46(3), 289-324.

Henrich, Joe, and Richard McElreath. (2003). The Evolution of Cultural Evolution. Evolutionary Anthropology 12(3): 123-35

Hirvonen, L. H. (2008). Intergenerational earnings mobility among daughters and sons: Evidence from Sweden and a comparison with the United States. American journal of Economics and Sociology, 67(5), 777-826.

Holmlund, H. (2008). Intergenerational Mobility and Assortative Mating: Effects of an Educational Reform. CEE DP 91. Centre for the Economics of Education (NJ1).

Hout, M. (1988). More universalism, less structural mobility: The American occupational structure in the 1980s. American Journal of Sociology, 93(6), 1358-1400.

Jencks, C., \& Tach, L. (2006). Would equal opportunity mean more mobility? Mobility and inequality: Frontiers of research from sociology and economics, 23-58.

Jenkins, S. (1987). Snapshots versus movies: lifecycle biases and the estimation of intergenerational earnings inheritance. European Economic Review, 31(5), 1149-1158.

Jensen, A. (1969). How much can we boost IQ and scholastic achievement? Harvard educational review, 39(1), 1-123.

Kalmijn, M., \& Flap, H. D. (2001). Assortative meeting and mating: Unintended consequences of organized settings for partner choices. Social Forces, 79(4), 1289-1312.

Knight, F. H. (1935). Professor Hayek and the theory of investment. The Economic Journal, 45(177), 77-94.

Lam, D., \& Schoeni, R. F. (1993). Effects of family background on earnings and returns to schooling: evidence from Brazil. Journal of Political Economy, 101(4), 710-740. 
Lam, D., \& Schoeni, R. F. (1994). Family ties and labor markets in the United States and Brazil. Journal of Human Resources, 1235-1258.

Lauman, E. O., Gagnon H. J., Michael, T. R. and Michaels S. (1994). The Social Organization of Sexuality. Sexual Practices in the United States. University of Chicago Press.

Mann, M. (1983). The Macmillan student encyclopedia of sociology: Gage Distribution Company.

Mare, R. D. (1991). Five decades of educational assortative mating. American Sociological Review, 15-32.

Mazumder, B. (2005). Fortunate sons: New estimates of intergenerational mobility in the United States using social security earnings data. Review of Economics and Statistics, 87(2), 235-255.

McCandless, S. E., Brunger, J. W., \& Cassidy, S. B. (2004). The burden of genetic disease on inpatient care in a children hospital. The American Journal of Human Genetics, 74(1), 121-127.

Meltzer, D. O. (1992). Mortality decline, the demographic transition, and economic growth. University of Chicago, Department of Economics.

Nickell, S. (1982). The determinants of occupational success in Britain. The Review of Economic Studies, 49(1), 43-53.

Ogbu, J. U. (2003). Black American students in an affluent suburb: A study of academic disengagement: Routledge.

Petrucelli, N. Daly, B.M. and Pal, T. 2007. BRCA1 and BRCA2 Hereditary Breast/Ovarian Cancer. Gene Reviews. http://genetests.org.

Ries, L. A., Harkins, D., Krapcho, M., Mariotto, A., Miller, B. A., Feuer, E. J., ...\& Hayat, M. (2006). SEER cancer statistics review, 1975-2003. Washington, D.C, National Cancer Institute.

Rutter, M., Silberg, J., O'Connor, T., \& Simonoff, E. (1999). Genetics and child psychiatry: II Empirical research findings. Journal of Child Psychology and Psychiatry, 40(1), 19-55.

Sewell, W., and R. Hauser, R. (1975). Education, Occupation, and Earnings: Achievements in the Early Career. New York: Academic Press.

Sjogren, A. (2000). Occupational Choice and Incentives: The Role of Family Background (No. 539). Research Institute of Industrial Economics. 
Solon, G. (1992). Intergenerational income mobility in the United States. The American Economic Review, 82(3), 393-408.

Solon, G. (2004). A model of intergenerational mobility variation over time and place. Generational income mobility in North America and Europe, 38-47.

Solon, G., Barsky, R., \& Parker, J. A. (1994). Measuring the cyclicality of real wages: how important is composition bias? The Quarterly Journal of Economics, 109(1), 1-25.

Soltow, L. (1965). Toward income equality in Norway: Madison, University of Wisconsin P.

Sorokin, P. A. 1927. Social Mobility. New York: Harper.

Streufert, P. (2000). The effect of underclass social isolation on schooling choice. Journal of Public Economic Theory, 2(4), 461-482.

Weil D (2009): Economic Growth (New Delhi: Pearson Education)

Wolff, P., \& Van Slijpe, A. R. D. (1973).The relation between income, intelligence, education and social background. European Economic Review, 4(3), 235264. 